\title{
ACUTUMINE INHIBITS PROLIFERATION OF MG-63 HUMAN OSTEOS ARCOMA CELLS VIA INDUCING ROS-MEDIATED APOPTOSIS
}

\author{
WENJI WANG ${ }^{1, \#}$, ZHAN WANG $^{2, \#}$, TONG ZHAO ${ }^{1}$, XIAOLIN LI', \\ TONG ZHANG ${ }^{1}$, JINCHI CAI ${ }^{1}$ and XINGWEN HAN ${ }^{1, *}$ \\ 'Department of Orthopaedics, The First Hospital of Lanzhou University, \\ Lanzhou, Gansu 730000, China \\ ${ }^{2}$ Department of Orthopaedics, Gansu Provincial Hospital, \\ Lanzhou, Gansu 730000, China
}

\begin{abstract}
Osteosarcoma (OS) is a severe malignant disease and possesses a despondent prognosis due to the lack of effective therapeutic approaches. To search novel therapy for the treatment of OS, we have evaluated acutumine using human OS MG-63 cells and investigated the possible mechanisms. The results revealed acutumine at $0.1,1$ and $10 \mu \mathrm{M}$ reduced the viability and inhibited the proliferating MG-63 cells, which resulted from the induced apoptosis. Further investigations have shown ROS-mediated mitochondrial dysfunction was involved in apoptosis via the intrinsic pathway. These findings gave information for further exploration in vivo and application of acutumine in practice for the treatment of OS.
\end{abstract}

Keywords: acutumine, osteosarcoma, MG-63cells, apoptosis, proliferation

Of all new cancer cases, osteosarcoma (OS) accounts for $0.2 \%$ and results in $0.3 \%$ of cancerrelated death worldwide (1). In the clinic, the character of OS is that the immature bone or osteoid tissue comprises directly malignant cells in children and adults (2). The major approaches for the treatment of OS include neoadjuvant chemotherapy and surgery. However, the prognosis for OS is still despondent due to the lack of specific therapy, which leads to the poor survival rate resulted from drug resistance, relapse, invasion and distant metastasis (3). Therefore, it is necessary to discover novel, effective and reliable treatment for OS.

In the discovery of new drugs targeting OS, some phytochemicals have been explored because of their wide distribution, abundant existence, and structural diversity. Acutumine (Fig. 1) is an alkaloid found in Sinomenium acutum (4), Menispermum dauricum (5), and Hypserpa nitida (6). Previous investigations have revealed acutumine afforded selectively cytotoxicity in T-cells (5). To search novel therapy for OS, its inhibitory effects, and possible mechanisms in MG-63 human osteosarcoma cells were explored herein.

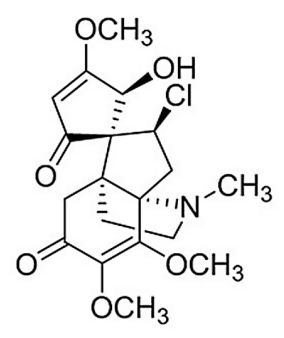

Figure 1. Chemical structure of acutumine.

\section{MATERIALS AND METHODS}

\section{Chemicals and reagents}

Acutumine was supplied by Shanghai Yuanye Bio-Technology Co., Ltd (Shanghai, China) and its purity was more than $98 \%$ analyzed by HPLC. 3-(4,5-dimethylthiazol-2-yl)-2,5-diphenyltetrazolium bromide (MTT) and dimethyl sulfoxide (DMSO) were provided by Sigma-Aldrich Inc (St. Louis, MO, USA). Dulbecco's Modified Eagle's Medium (DMEM) was purchased from Invitrogen Gibco Co., Ltd (Grand Island, NY, USA). Bicinchoninic acid (BCA) assay kit was supplied

\footnotetext{
* Corresponding author: e-mail: hxwbone@126.com

${ }^{\#}$ These authors contributed equally to this work
} 
by from Nanjing Jiancheng Bioengineering Institute (Nanjing, China). Hoechst 33258 staining solution, reactive oxygen species (ROS) assay kit, mitochondrial membrane potential assay kit, crystal violet staining solution, caspase-3 assay kit, horseradish peroxidase (HRP) labeled secondary antibody, enzyme-link chemiluminescence (ECL) kit and $\mathrm{N}$-acetyl cysteine (NAC) were gained from Beyotime Biotechnology Institute (Shanghai, China). Primary antibodies against Bcl-2, Bax, cytochrome c, cleaved caspase-3, and $\beta$-actin were obtained from Cell Signaling Technology, Inc. (Danvers, MA, USA).

\section{Cell culture and treatment}

Human osteosarcoma MG-63 cells were provided by American Type Culture Collections (ATCC, Manassas, VA, USA) and maintained in DMEM including 10\% FBS, $100 \mathrm{U} / \mathrm{mL}$ penicillin $\mathrm{G}$ and $100 \mu \mathrm{g} / \mathrm{mL}$ streptomycin at $37^{\circ} \mathrm{C}$ at a humidified atmosphere with $5 \% \mathrm{CO}_{2}$ and $95 \%$ air. The cells were assigned as the control group and experimental groups. The cells in the control group were just subjected to the culture medium. And the cells in experimental groups were exposed to certain concentrations of acutumine $(0.1,1$ and $10 \mu \mathrm{M}$ as final concentrations) for $24 \mathrm{~h}$. Human normal osteoblasts were supplied by Procell Life Science \& Technology Co, Ltd. (Wuhan, China) and cultured in DMEM with FBS, glutamine, penicillin and streptomycin under humid conditions at $37^{\circ} \mathrm{C}$ with $5 \% \mathrm{CO}_{2}$ and $95 \%$ air.

\section{MTT assay}

To detect the viability of MG-63 cells exposed to acutumine, MTT assay was carried out. Briefly, cells were seeded in 96-well plates at a density of $1 \times 10^{4}$ cells per well. When $70-80 \%$ confluence, the cells were treated with or without indicated concentrations of acutumine for $24 \mathrm{~h}$. Subsequently, the culture medium was replaced with fresh culture medium containing MTT $(1 \mathrm{mg} / \mathrm{mL})$ and the cells were incubated for $4 \mathrm{~h}$. And $100 \mu \mathrm{L}$ was introduced to dissolve the formazan. The absorbance at $570 \mathrm{~nm}$ was recorded on a SpectraMax M5 microplate reader (Molecular Devices, Sunnyvale, CA, USA) and the relative cell viability was expressed as a percentage of absorbance from experimental groups against the control group. Meanwhile, to explore the cytotoxic effects of acutumine on normal cells, MTT assay was also carried out for the human normal osteoblasts treated with certain acutumine (0.01$100 \mu \mathrm{M})$ as above.

\section{Hoechst 33258 staining}

The cells were seeded in 96-well plates at a density of $1 \times 10^{4}$ cells per well. After exposure to indicated acutumine for $24 \mathrm{~h}$, the cells were rinsed with PBS twice. Then at room temperature, $4 \%$ paraformaldehyde was added to fix the cells. After $30 \mathrm{~min}$, the addition of Hoechst $33258(1 \mu \mathrm{g} / \mathrm{mL})$ was performed to stain the cells. After $10 \mathrm{~min}$, the morphology of cell nuclei was visualized under a fluorescence microscope (Olympus, Tokyo, Japan).

\section{Colony formation assay}

To evaluate the effects of acutumine on the proliferating MG-63 cells, colony formation assay was implemented as a previous description (7). The cells were seeded in 6 -well plates at $5 \times 10^{3}$ cells per well and incubation was implemented at $37^{\circ} \mathrm{C}$ for 24 $\mathrm{h}$. Then the cells were exposed to certain acutumine for another $24 \mathrm{~h}$. After replacing acutumine with the fresh culture medium, the cells were incubated for 10 days. Then, $4 \%$ of paraformaldehyde was used to fix the cells at $-20^{\circ} \mathrm{C}$. After $15 \mathrm{~min}, 0.1 \%$ crystal violet was employed to stain the cells at room temperature. After another $15 \mathrm{~min}$, the images of colonies were recorded using a SONY digital camera (SONY, Tokyo, Japan).

\section{Production of intracellular ROS}

To detect the production of intracellular ROS, the ROS assay kit was employed in light of the manufacturer's instructions. The treated cells were washed with PBS. Then cells were incubated with $10 \mu \mathrm{M}$ DCFH-DA in the assay kit at $37^{\circ} \mathrm{C}$ for 20 min. After rinsed twice with PBS, intracellular ROS was detected on a fluorescence microplate reader at $485 / 520 \mathrm{~nm}$ as ex/em wavelength.

\section{Mitochondrial membrane potential assay}

According to the supplier's instruction, the mitochondrial membrane potential in MG-63 cells was monitored by means of the assay kit. In brief, MG-63 cells were seeded in 6-well plates and treated as above. Then the cells were treated with indicated acutumine for $24 \mathrm{~h}$. After detachment with trypsin solution, $1 \mathrm{mg} / \mathrm{mL}$ JC- 1 solution in the assay kit was added. Thereafter the incubation was implemented in the dark at $37 \mathrm{~s} C$ for $20 \mathrm{~min}$, and then rinsed with PBS. The fluorescence intensity was measured on the SpectraMax M5 microplate reader. The excitation wavelength was set at $525 \mathrm{~nm}$ and the emission wavelength at $590 \mathrm{~nm}$. The mitochondrial membrane potential was derived from the relative percentage of fluorescence intensity in experimental groups versus the control group. 


\section{Caspase-3 activity}

The activity of caspase- 3 in MG-63 cells was determined using the colorimetric assay kit following the supplier's protocol. The treated cells were rinsed with PBS and lysed on ice-cold lysis buffer. After centrifugation, the supernatant was collected as samples. After incubation with a specific substrate (Ac-DEVD-pNA) at $37^{\circ} \mathrm{C}$ for $2 \mathrm{~h}$, the absorbance was read on a microplate reader at 405 nm. The activity of caspase- 3 was calculated from absorbance for pNA produced by caspase-3 against that of the control group.

\section{Western blot analysis}

The treated cells were lysed on ice-cold lysis buffer and centrifuged at $10000 \times \mathrm{g}$ for $15 \mathrm{~min}$ at $4^{\circ} \mathrm{C}$. The supernatant was collected as a sample for the following analysis. Then the proteins were quan-

(a)

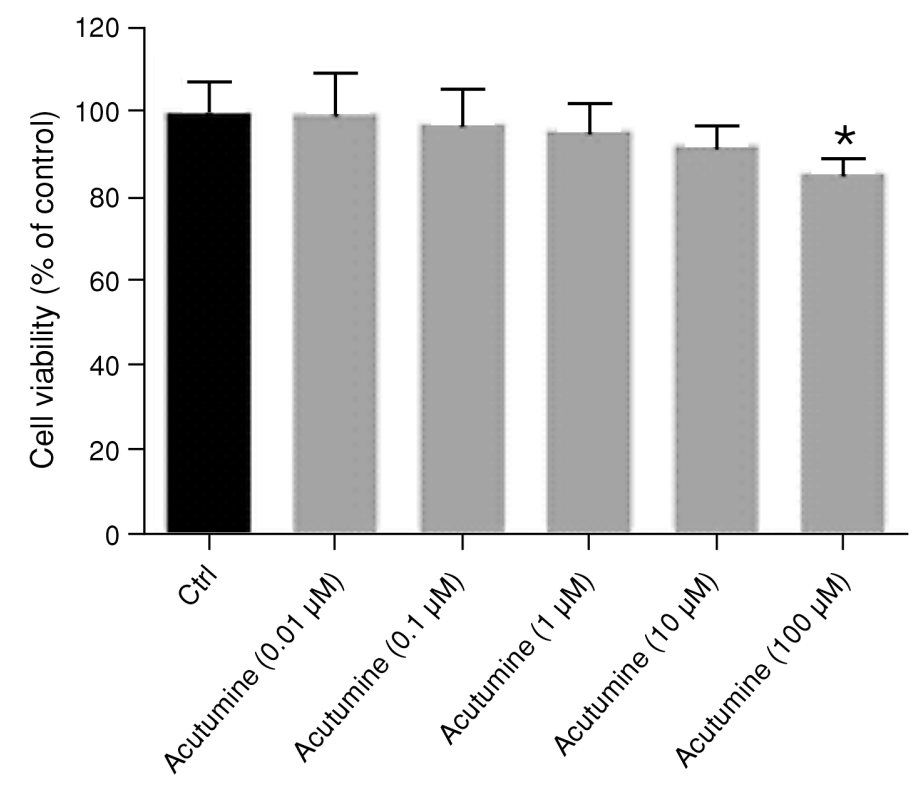

(b)

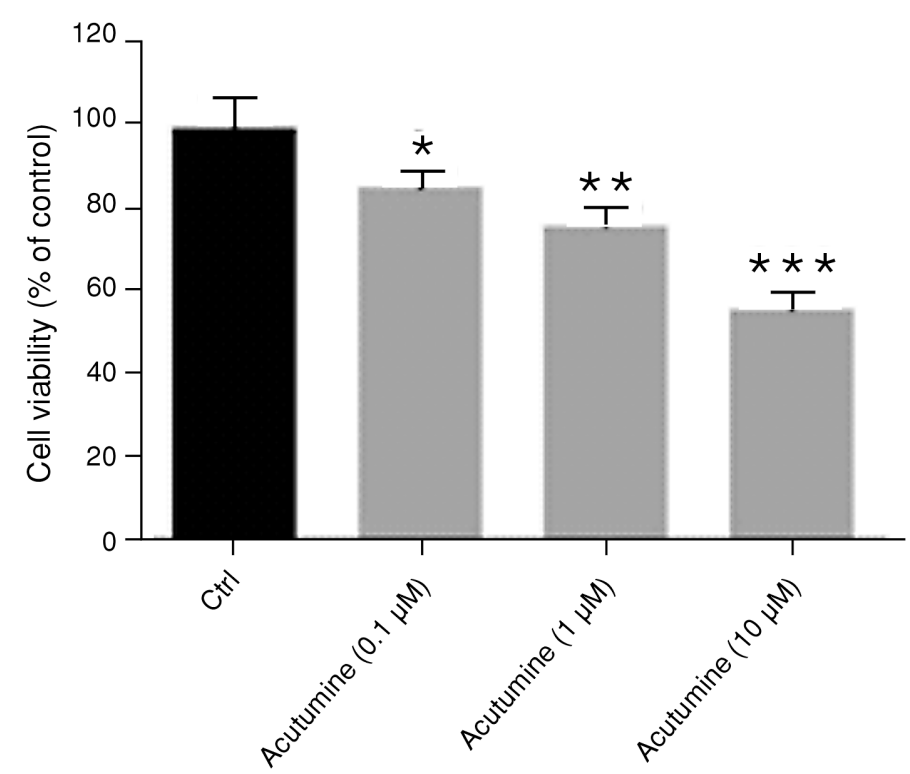

Figure 2. Effect of acutumine on cell viability. (a) Viability of human normal osteoblasts treated with acutumine; (b) viability of MG-63 cells treated with acutumine. $\mathrm{n}=3,{ }^{*} \mathrm{P}<0.05,{ }^{* *} \mathrm{P}<0.01$, and ${ }^{* * *} \mathrm{P}<0.001$ versus control group. 
tified using a BCA assay kit. After that equal amounts of protein samples $(50 \mu \mathrm{g})$ were separated on $15 \%$ SDS-PAGE. Thereafter, the bands were transferred onto polyvinylidene fluoride (PVDF) membranes and with $5 \%$ defatted milk for $1 \mathrm{~h}$ at room temperature. And then incubation with respective primary antibodies including anti-Bcl-2 (1: 1000), anti-Bax (1: 1000), anti-cytochrome c (1: 1000), anti-cleaved caspase-3 (1: 1000) and anti- $\beta$-actin $(1: 1000)$ was carried out overnight at $4^{\circ} \mathrm{C}$. After rinsed three times with Tris buffer including $0.1 \%$ Tween-20, the membranes were subjected to the corresponding HRP-conjugated secondary antibody $(1: 1000)$ in blocking solution at room temperature for $2 \mathrm{~h}$. The bands were visualized with an ECL kit. And the band density was monitored using free Image J software (NIH, Bethesda, USA), normalized by $\beta$-actin, and quantified through the ratio of the densitometric values.

\section{Inhibitor treatment}

To further elucidate the role of ROS in the apoptosis of MG-63 cells, N-acetyl cysteine (NAC), a common inhibitor of ROS was employed. The MG63 cells were treated with $5 \mathrm{mM}$ NAC for $2 \mathrm{~h}$ before exposed to certain acutumine. Then the cells were treated as above and MTT assay was implemented.

\section{Data analysis}

All the experimental data were expressed as means \pm standard deviation and analyzed by GraphPad Prism 5.0 (GraphPad Software, Inc., La Jolla, CA, USA). One way ANOVA followed by Dunnett's test was used for multiple comparisons as well as Student's t-test for single comparisons. And $\mathrm{P}<0.05$ was regarded as statistical significance.

\section{RESULTS}

Effects of acutumine on the survival of MG-63 cells

As shown in Figure 2a, the viability of normal osteoblasts was not inhibited significantly by acutumine at $10 \mu \mathrm{M}$ though the inhibition was found with acutumine at $100 \mu \mathrm{M}$. However, after treated with certain acutumine, the viability of MG-63 cells was
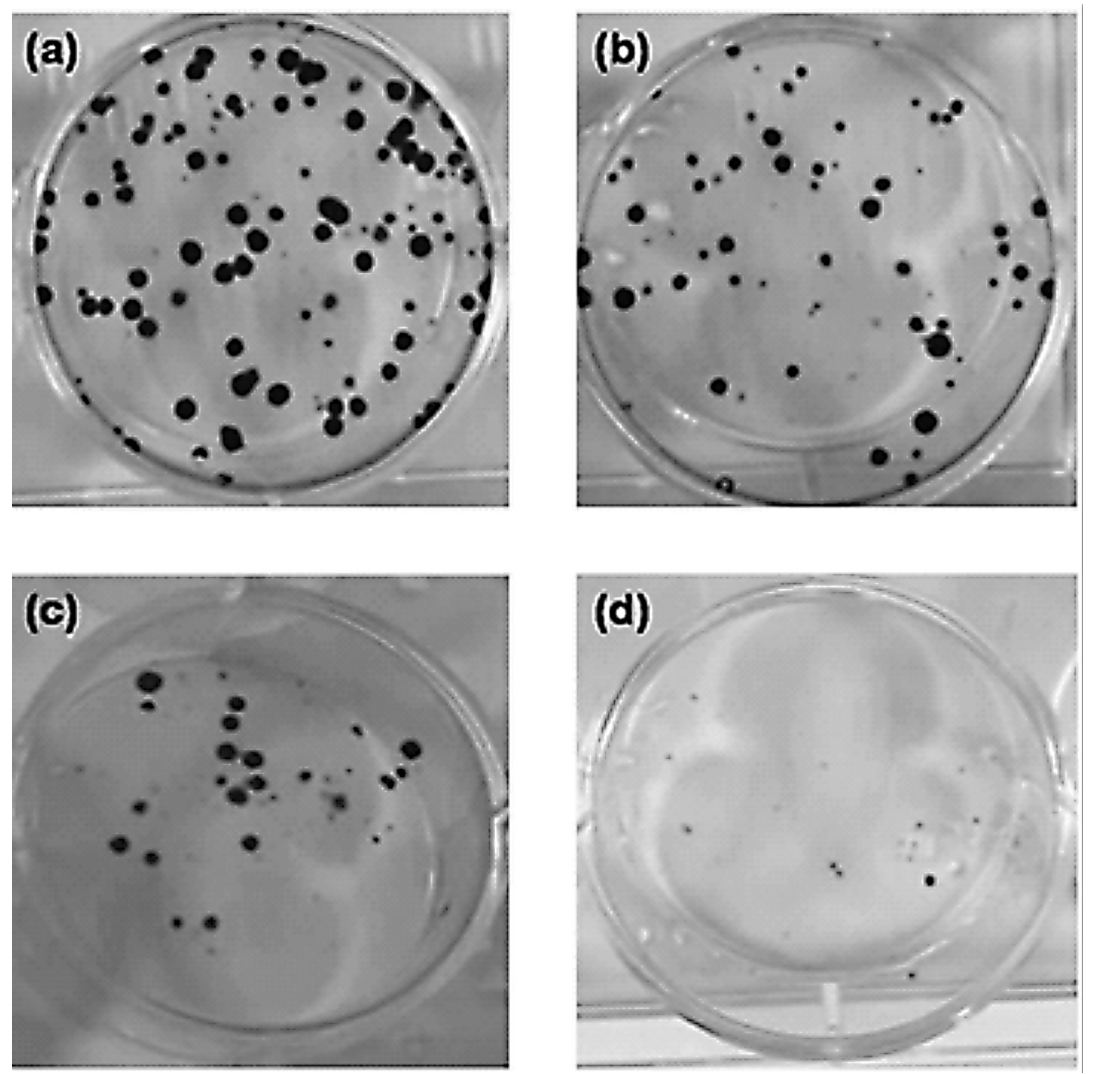

Figure 3. Colony formation assay for MG-63 cells. (a) Control group; (b) acutumine $(0.1 \mu \mathrm{M})$; (c) acutumine (1 $\mu \mathrm{M})$; (d) acutumine $(10 \mu \mathrm{M})$. 

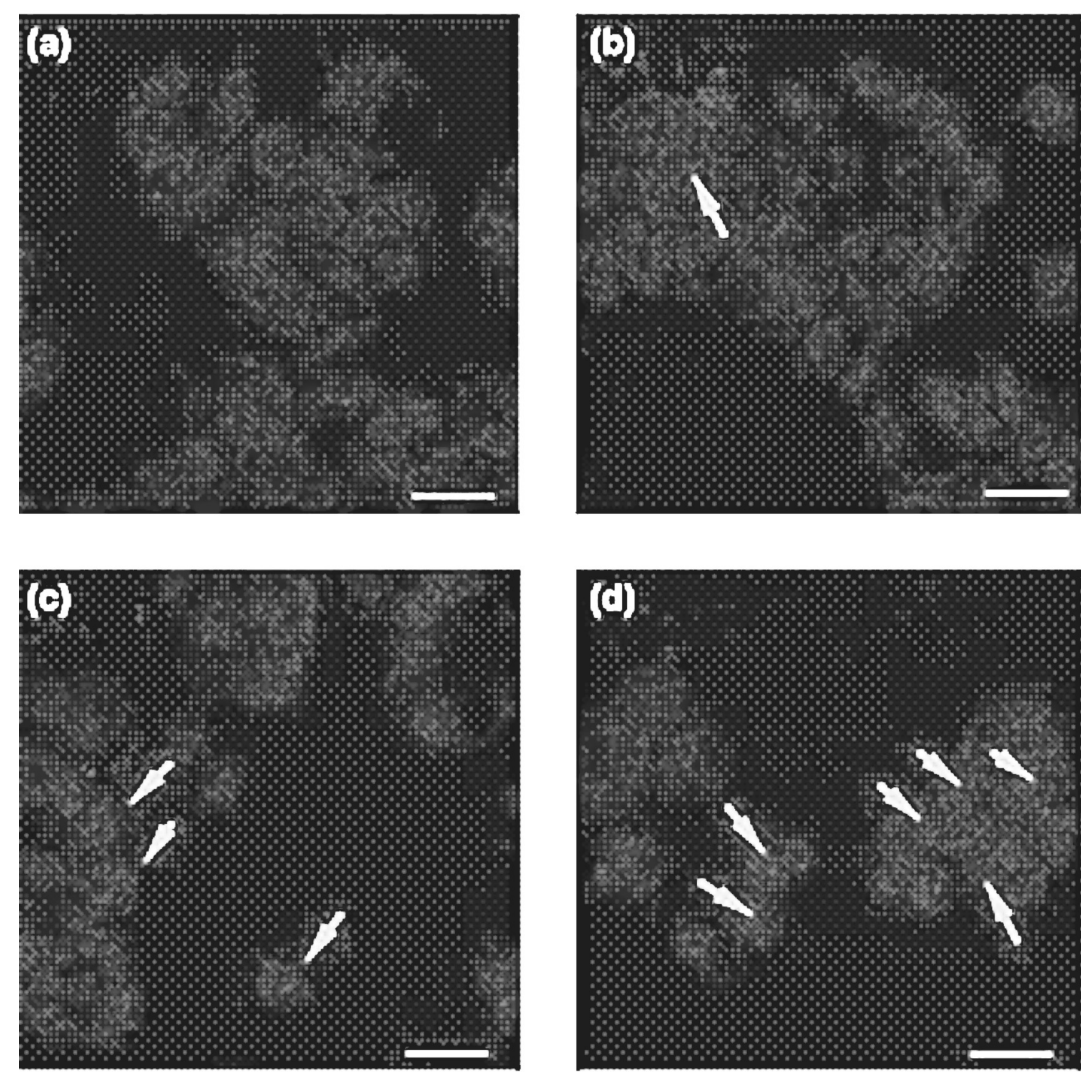

Figure 4. Hoechst 33258 staining of MG-63 cells. (a) Control group; (b) acutumine $(0.1 \mu \mathrm{M})$; (c) acutumine (1 $\mu \mathrm{M})$; (d) acutumine $(10 \mu \mathrm{M})$.

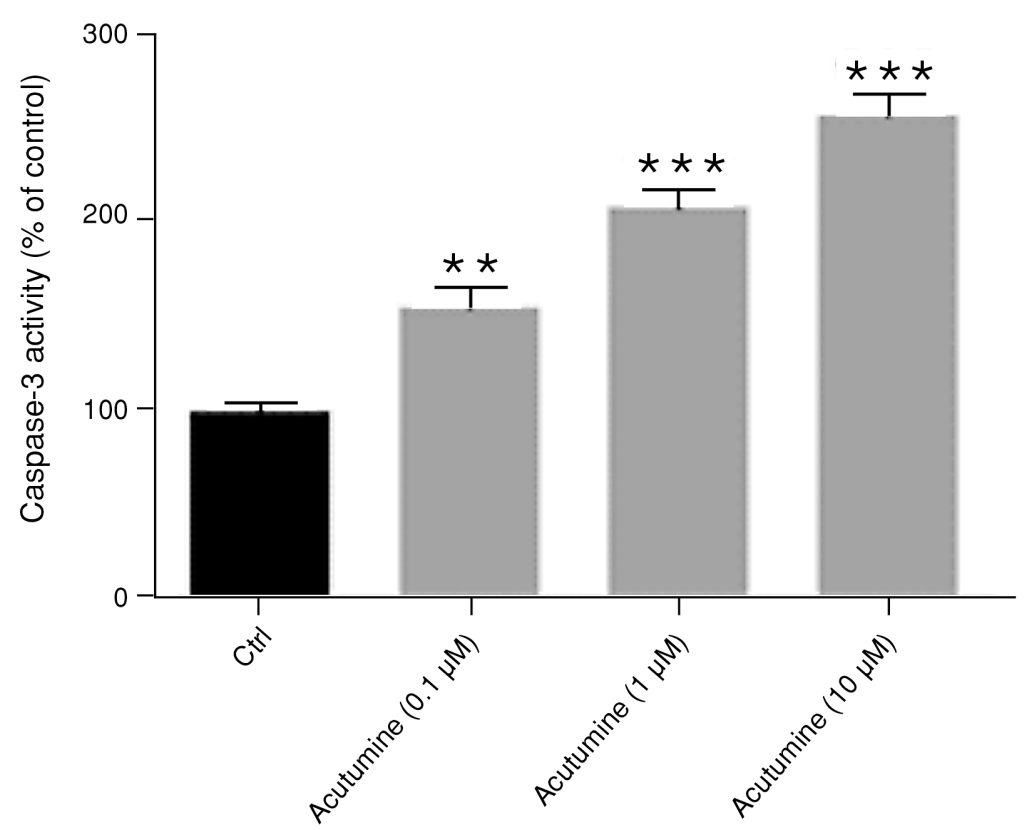

Figure 5. Caspase-3 activity in MG-63cells by colorimetric method. $\mathrm{n}=3,{ }^{* *} \mathrm{P}<0.01$, and ${ }^{* * *} \mathrm{P}<0.001$ versus control group. 
(a) Cytochromec

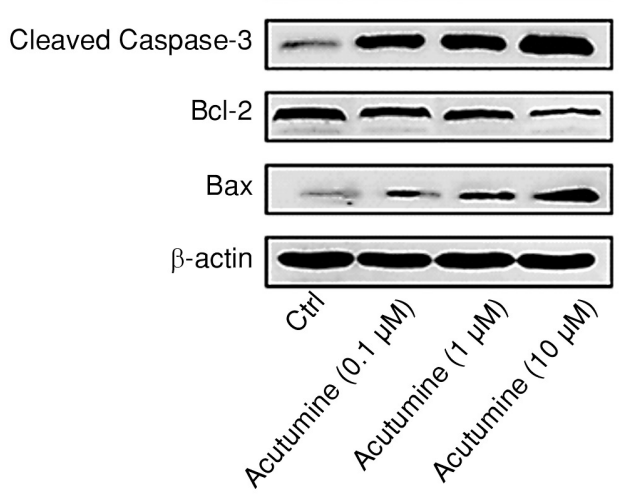

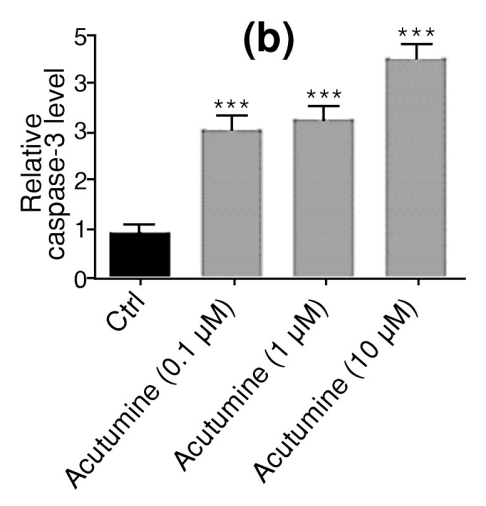
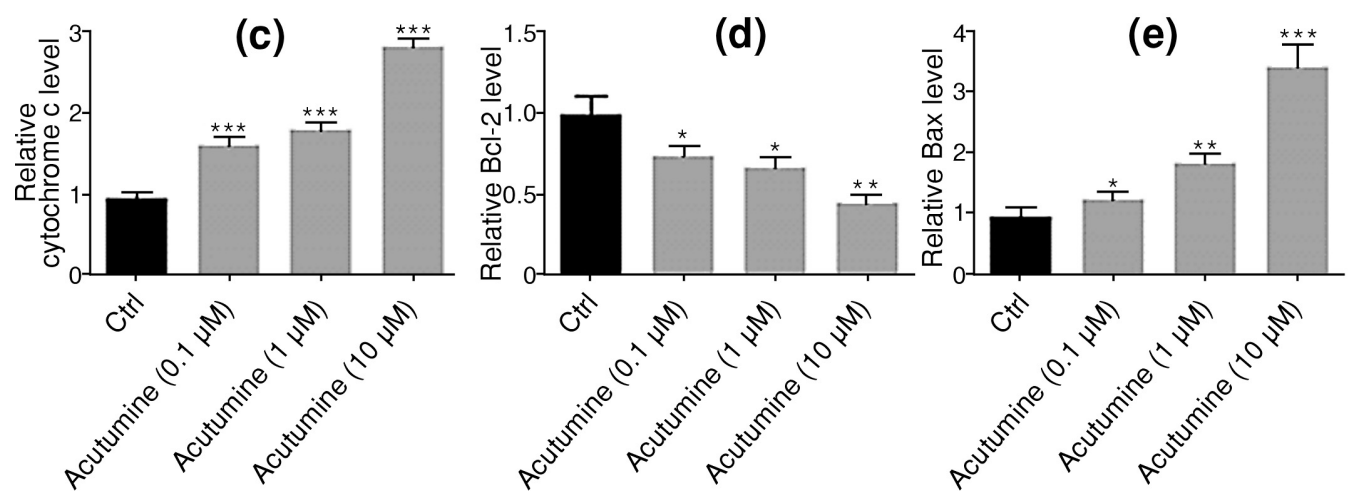

Figure 6. Apoptosis of MG-63 cells induced by acutumine underwent intrinsic pathway. (a) Western blot analysis; (b) relative expression of caspase-3; (c) relative expression of cytochrome c; (d) relative expression of Bcl-2; (e) relative expression of Bax. $\mathrm{n}=3$, ${ }^{*} \mathrm{P}<0.05$, ${ }^{* *} \mathrm{P}<0.01$, and ${ }^{* * *} \mathrm{P}<0.001$ versus control group.

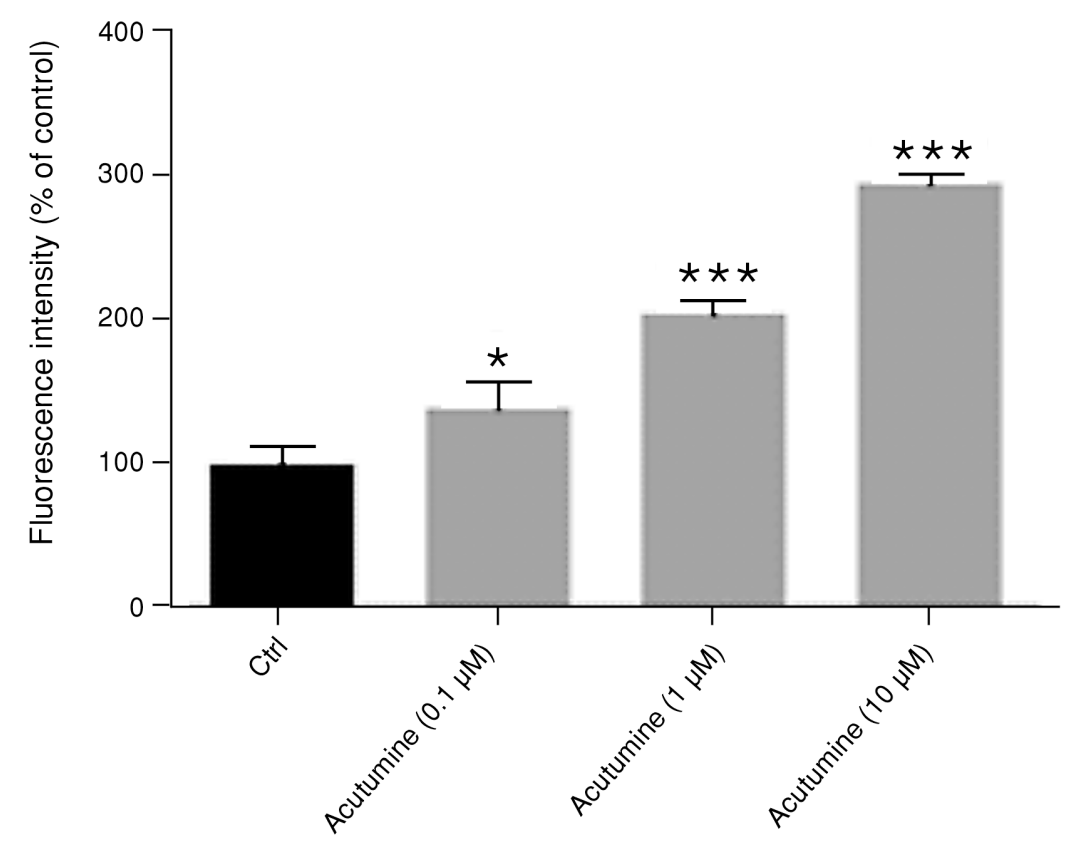

Figure 7. Overproduction of ROS in MG-63 cells. $\mathrm{n}=3,{ }^{*} \mathrm{P}<0.05$, and ${ }^{* * *} \mathrm{P}<0.001$ versus control group. 


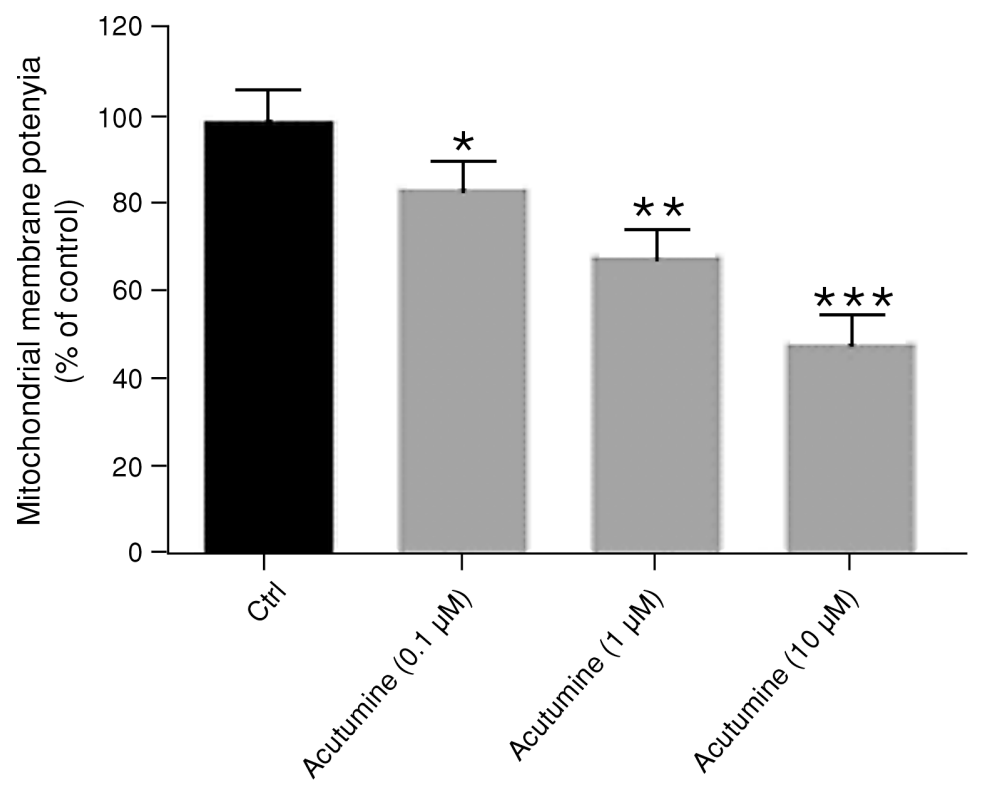

Figure 8. Collapse of mitochondrial membrane potential in MG-63 cells. $\mathrm{n}=3,{ }^{*} \mathrm{P}<0.05,{ }^{* *} \mathrm{P}<0.01$, and ${ }^{* * *} \mathrm{P}<0.001$ versus control group.

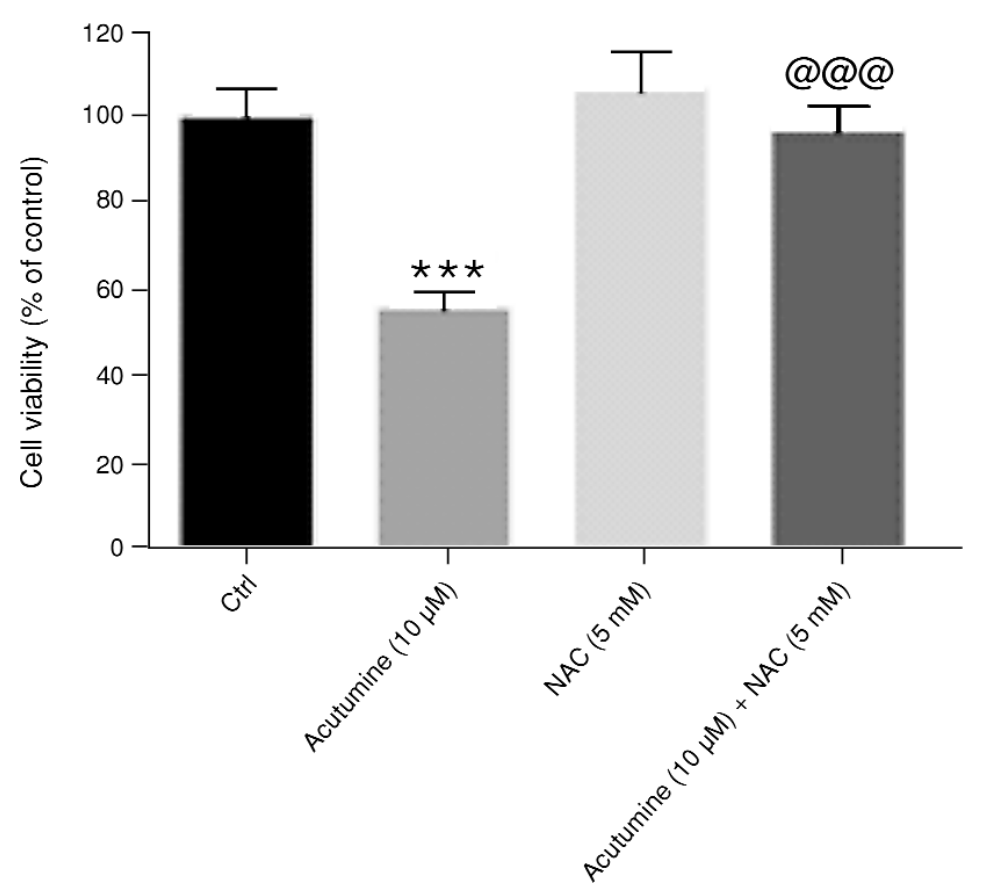

Figure 9. Effect of NAC on the apoptosis of MG-63 cells induced by acutumine. $\mathrm{n}=3,{ }^{* * *} \mathrm{P}<0.001$ versus control group, @@@ $\mathrm{P}<0.001$ versus acutumine $(10 \mu \mathrm{M})$ group.

reduced $(85.8 \pm 4.0 \%, 76.4 \pm 4.5 \%$ and $56.2 \pm 4.2 \%)$ in a concentration-dependent manner compared to the control group (100.0 $\pm 7.7 \%$ ) (Fig. 2b). Further colony formation assay has shown acutumine can decrease the formation of a colony in MG-63 cells in a concentration-dependent manner (Fig. 3), which indicated the proliferation of MG-63 cells was inhibited by acutumine.

\section{Acutumine induces apoptosis of MG-63 cells}

To further explore the inhibitory effect of acutumine on MG-63 cells, Hoechst 33258 staining was 
performed to observe the nuclear morphology. As a result, normal nuclei displayed dispersed and weak fluorescence, whereas with certain acutumine the nuclei emitted condensed and asymmetric fluorescence due to the chromatin condensation and DNA fragmentation, which revealed apoptosis occurred in MG-63 cells in the presence of acutumine (Fig. 4).

The apoptosis induced by acutumine undergoes an intrinsic pathway

As the effector enzyme, the activity of caspase3 in MG-63 cells was monitored to elucidate the mechanism of apoptosis induced by acutumine. As shown in Figure 5, compared to control group (100.0 $\pm 5.4 \%$ ), caspase- 3 activity in MG-63 cells was elevated remarkably $(154.7 \pm 11.0 \%, 208.0 \pm 9.4 \%$ and $256.5 \pm 11.6 \%$ ). Meanwhile, western blot analysis has also exhibited acutumine up-regulated the expression of active caspase-3 (Fig. 6a and b). As the key node in intrinsic apoptosis, cytochrome c will release into the cytosol from mitochondria. Herein, cytochrome $\mathrm{c}$ in the cytosol was analyzed by western blot to disclose the release of cytochrome $\mathrm{c}$ from mitochondria. The result demonstrated the expression of cytochrome c was up-regulated in MG-63 cells following the addition of acutumine (Fig. 6a and c). Then the upstream proteins including Bcl-2 and Bax were detected by western blot analysis. And the expression of Bcl-2 was down-regulated while Bax was up-regulated (Fig. 6a, d and e). These findings implied the intrinsic pathway was involved in the apoptosis of MG-63 cells induced by acutumine.

ROS mediates the apoptosis induced by acutumine in MG-63 cells

To further reveal the mechanism, the level of ROS in MG-63 cells was monitored with or without acutumine (Fig. 7). Compared to control group $(100.0 \pm 13.9 \%)$, acutumine can elevate ROS levels $(139.0 \pm 19.2 \%, 204.8 \pm 10.3 \%$ and $295.1 \pm 7.4 \%)$ significantly. Since mitochondria are the major site for the generation of ROS, the mitochondrial membrane potential in MG-63 cells was detected (Fig. 8). It was observed acutumine could result in the depolarization of mitochondrial membrane potential in MG-63 cells in a concentration-dependent manner $(84.5 \pm 6.0 \%, 69.1 \pm 6.0 \%$ and $49.0 \pm 6.5 \%)$ by comparison with the control group $(100.0 \pm 7.5 \%)$. To further validate the effect of ROS on the apoptosis induced by acutumine, the ROS inhibitor NAC was used to inhibit the redox status in MG-63 cells. The result showed in the presence of NAC, The reduced viability of MG-63 cells resulting from acutumine was reversed (Fig. 9). These results impli- cated ROS-mediated mitochondrial dysfunction was involve in the apoptosis.

\section{DISCUSSION}

As a serious malignant cancer, OS has afflicted the physical and mental health of human beings all over the world. Since the side effects and drug resistance to chemotherapy, the discovery of new drugs targeting OS is imperative (7). In our present studies, we have evaluated the inhibitory effects of acutumine on the human OS MG-63 cells and found it could reduce the viability and inhibit the proliferating MG-63 cells via inducing apoptosis.

In apoptosis, caspase- 3 affords the morphological changes such as mitochondrial damage, nuclear membrane breakdown, DNA fragmentation, chromatin condensation, and the formation of apoptotic bodies (8). As the key member of aspartate-specific cysteine proteases, caspase- 3 is activated through the proteolysis from procaspase- 3 at the aspartate residues (9). Bcl-2 and Bax are major members of Bcl-2 protein family as central regulators of caspases (10). Bcl2 is anti-apoptotic while Bax is pro-apoptotic. Bcl-2 can form a heterodimer with Bax to prohibit the release of cytochrome c (11). Therefore, the opposing factions of Bcl-2 and Bax arbitrate the life-or-death decision. Overexpression of Bax will give rise to the release of cytochrome $\mathrm{c}$, and the latter activates the caspase-3 via signaling cascades (12). Herein, we have found acutumine elevated the activity of caspase3 through up-regulating activated caspase-3. Further analysis has revealed this effect was associated with the up-regulation of Bax together with down-regulation of Bcl-2 and following release of cytochrome c.

As the major site of ROS generation, mitochondria play a crucial role in apoptosis (13). Due to the oxidation of DNA, proteins and lipids, the overproduction of ROS will result in apoptosis through the mitochondrial dysfunction (14). The collapse of mitochondrial membrane potential is an early event in apoptosis, which results from the mitochondrial membrane damage and indicates the mitochondrial function (15). Our results have implied that acutumine promoted the overproduction of ROS in MG63 cells and brought about the collapse of mitochondrial membrane potential, which indicates the ROS-mediated mitochondrial dysfunction is implicated in acutumine-induced apoptosis.

\section{CONCLUSION}

In conclusion, we have found acutumine inhibited the proliferation of MG-63 cells through induc- 
ing apoptosis via the intrinsic pathway. And further investigations have elucidated the apoptosis is closely relevant to ROS-mediated mitochondrial dysfunction. These facts can supply information for the following investigation in vivo and the application for the treatment of OS.

\section{Conflict of interests}

The authors declare no conflict of interest.

\section{REFERENCES}

1. Zhao L., Li J., Sun Z.B., Sun C., Yu Z.H., Guo X.: Exp. Ther. Med. 17, 488 (2019).

2. Widhe B., Widhe T.: J. Bone Joint Surg. Am. 82, 667 (2000).

3. Pan Z., Wang S.K., Cheng X.L., Tian X.W., Wang J.: Bangladesh J. Pharmacol. 11, 817 (2016).

4. Tomita M., Okamoto Y., Kikuchi T., Osaki K., Nishikawa M., et al.: Tetrahedron Lett. 25, 2421 (1967).
5. Yu B.W., Chen J.Y., Wang Y.P., Cheng K.F., Li X.Y., Qin G.W.: Phytochemistry 61, 439 (2002).

6. Cheng P., Ma Y.B., Yao S.Y., Zhang Q., Wang E.J., et al.: Bioorg. Med. Chem. Lett. 17, 5316 (2007)

7. Ma K., Zhang C., Huang M.Y., Li W.Y., Hu G.Q.: Oncol. Rep. 36, 90 (2016).

8. Thornberry N.A., Lazebnik Y.: Science 281, 1312 (1998).

9. Earnshaw W.C., Martins L.M., Kaufmann S.H.: Annu. Rev. Biochem. 68, 383 (1999).

10. Ola M.S., Nawaz M., Ahsan H.: Mol. Cell. Biochem. 351, 41 (2011).

11. Cory S., Adams J.M.: Nat. Rev. Cancer 2, 647 (2002).

12. Scorrano L., Korsmeyer S.J.: Biochem. Biophys. Res. Commun. 304, 437 (2003).

13. Xiong S., Mu T., Wang G., Jiang X.: Protein Cell 5, 737 (2014).

14. Redza-Dutordoir M., Averill-Bates D.A.: Biochim. Biophys. Acta 1863, 2977 (2016).

15. Lleonart M.E., Grodzicki R., Graifer D.M., Lyakhovich A.: Med. Res. Rev. 37, 1275 (2017).

(C) 2020 by Polish Pharmaceutical Society. This is an access article under the CC BY NC license (http://creativecommons.org/licenses/by-nc/4.0/). 